\title{
PEREMPUAN DAN PENDIDIKAN DALAM PERSPEKTIF HAM
}

\author{
Bahrul Hayat \\ Sekretaris Jenderal Kementerian Agama \\ Email: wawandjunaedi@yahoo.com .
}

\section{Abstract}

This paper discusses the participation of women education in the perspective of buman rigbts. The research is freld study with a sample distribution from elementary School to college with the scope of researb on aspects of illiteragy, formal education, and non-formal education. The research showed that the cause of gender disparity in education is closely related to religious, social, economic, cultural, and geagrapbycal factors. Altbough from legal aspert and educational policy, men and women are given equal access, but the various constraints restrict somen's struggle to obtain equality of educational opportunities.

مستغلص

هذه المقالة معبِّة عن دور المرأة في التوبية في وجه حقوق الإنسانية. هذه تؤخذ من تحقيق الواقع بنشرة مثال المدرمسة الابتدائية حتى الجامعة. و هذا التحقيق يشتمل على ناحية الأمى دئ والتتبية الرسمية وغير الرسمية. فهاك رأس الخلاف الجنسيى و هذا يتعلق بعامل الليين و الاجتماع والاقتصاد والثقاقة والجروفية تعلُقا. و لو كانث المساوة بين الطالب والطالبة لكن النية تصعب الطظالبة في حصبول تلك المنساوة.

Keywords: Perempuan, Pendidikan, Hak Asasi Manusia, Kesetaraan, Partisipasi 


\section{A. Pendahuluan}

Sebagaimana diamanatkan dalam undang-undang, titik berat pembangunan nasional adalah pembangunan bidang ekonomi sejalan dengan peningkatan kualitas sumberdaya manusia. Pengembangan sumber daya manusia berkait erat dengan pendidikan, pelatihan, pemanfaatan potensi sumber daya manusia untuk kemajuan ekonomi dan sosial. Menurut UNDP ada lima 'pembangkit energi' pengembangan sumber daya manusia yaitu pendidikan, kesehatan, lingkungan, employment, dan kebebasan ekonomi dan politik. Kelima pembangkit energi tersebut berkait dan saling bergantung sate samà lain, akan tetapi pendidikan merupakan dasar untuk pembangkit energi yang lainnya. Pendidikan merupakan faktor esensial dalam peningkatan kesehatan, mempertahankan lingkungan yang berkualitas, memperluas dan meningkatkan tenaga kerja, dan melanggengkan (sustaining) tanggung jawab politik dan ekonomi. Pendidikan dan pengembangan sumber daya manusia merupakan kekuatan pendorong (driving force) pembangunan.

Di sisi lain pendidikan merupakan institusi sosial utama yang memungkinkan tercapainya demokrasi dan ekualitas. Melalui pendidikan, budaya ditransformasi, fungsi dan status sosial direproduksi dan diciptakan. Dalam konteks sosial apapun, fungsi transformasi pendidikan tak dapat dielakkan karena menyentuh secara sosial dan ekonomi masyarakat lapisan bawah yang kurang beruntung. Transformasi pendidikan mengakibatkan egalitarian dan terbentuknya sistem sosial meritokrasi. Suatu sistem meritokrasi, sebagai lawan dari aristokrasi, adalah suatu sistem sosial di mana semua angota masyarakat diberi kesempatan yang sama untuk mengembangkan kemampuannya dan mendaki hirarki sosial. Secara ringkas, pada tingkat makro pendidikan mempunyai fungsi politis, sosial, dan ekonomi.

Sementara itu, dilihat dari sudut individu, tujuan pendidikan (Goodlad, 1984) meliputi aspek a) sosial (penyiapan untuk kehidupan sosial pada masyarakat yang semakin kompleks), b) intelektual (pengetahuan dan keterampilan akademik), c) personal (pengembangan tanggung jawab dan talenta individu), dan d) vokasional (persiapan untuk memasuki dunia kerja) . 
Partisipasi individu, termasuk perempuan, dalam dunia pendidikan pada akhirnya bertujuan untuk memperoleh kesempatan pekerjaan yang memungkinkan seseorang melakukan mobilitas sosial. Masyarakat, terlepas dari tingkatan sosialnya, mempunyai aspirasi dan keyakinan yang tinggi bahwa pendidikan merupakan sarana untuk mobilitas sosial. Sebagai konsekuensi logis, pendidikan yang bernuansa segregasi gender merupakan sarana untul mempertahankan masyarakat yang berstrata dengan membiarkan perempuan terpisah dari rute karir yang tersedia bagi sebagian besar masyarakat.

Berbicara mengenai pendidikan sebagai alat mobilitas sosial bagi setiap individu, sejumlah aturan internasional maupun nasional telah dirumuskan. Aturan-aturan ini dibuat untuk menjamin setiap individu, baik perempuan maupun laki-laki, untuk mendapatkan pendidikan yang bermutu, membebaskan, dan nondiskriminatif. Uraian berikut akan memberikan deskripsi singkat bagaimana pendidikan sebagai hak dasar setiap individu diproteksi dalam sejumlah aturan internasional yang juga telah diratifikasi sejumlah negara dunia yang kemudian dijabarkan dalam aturan-aturan pada level nasional.

\section{B. Pendidikan Sebagai Hak Dasar Manusia}

Berbicara mengenai hak minimum individu yang juga sering disebut dengan istilah minimum core content of rights, isu yang sering muncul adalah mengenai hak hidup, hak untuk mendapatkan rasa aman, hak untuk mendapatkan jaminan kesehatan, dan hak untuk mendapatkan pendidikan yang layak. Hak-hak dasar yang baru disebutkan sebenarnya merupakan hak asasi manusia yang telah dibawa sejak lahir. Namun pada kenyataannya, setiap individu tidak secara otomatis bisa diperoleh hak-hak dasar tersebut. Tidak jarang hak dasar individu dirampas oleh sebuah kekuatan (power), baik secara personal maupun institusional, secara sporadis maupun sistematis... Dalam konteks inilah keberadaan pemerintah (negara) yang berdaulat menjadi sangat penting. Melalui pemerintahan yang berdaulat, hak-hak individu (baca: rakyat) diharapkan bisa terjamin dan tidak dilanggar.

Sebagaimana telah disinggung di atas, di antara hak dasar setiap individu adalah hak untuk mendapatkan pendidikan yang layak. Pendidikan ménjadi 
sangat penting bagi individu, karena hanya dengan pendidikan seseorang bisa berpengetahuan, bermartabat, dan pada akhirnya mendapatkan kehidupan yang layak di tengah komunitasnya. Di antara aturan internasional yang memberikan jaminan pendidikan adalah Deklarasai Universal Hak-hak Asasi Manusia (DUHAM) tahun 1948, tepatnya pada Pasal 26 sebagai berikut:

(1) Setiap orang berhak memperoleh pendidikan. Pendidikan harus dengan cumacuma, setidak-tidaknya untuk tingkatan sekolah rendah dan pendidikan dasar. Pendidikan rendah harus diwajibkan. Pendidikan teknik dan kejuruan secara umum harus terbuka bagi semua orang, dan pendidikan tinggi harus dapat dimasuki dengan cara yang sama oleh semua orang, berdasatkan kepantasan.

(2) Pendidikan harus ditujukan ke arah perkembangan pribadi yang seluas-luasnya serta untuk mempertebal penghargaan terhadap hak asasi manusia dan kebebasan-kebebasan dasar. Pendidikan harus menggalakkan saling pengertian, toleransi dan persahabatan di antara semua bangsa, kelompok ras maupun agama, serta harus memajukan kegiatan Perserikatan Bangsa-Bangsa dalam memelihara perdamaian.

Dari redaksi DUHAM di atas dapat diketahui dengan tegas bahwa setiap individu berhak memperoleh pendidikan, setidaknya pendidikan dasar. Ketika sebagian masyarakat sulit untuk mendapatkan hak pendidikan yang merupakan hak dasamya, pihak yang betkewajiban untuk memenuhi hak tersebut tidak lain adalah negara. Sadar akan kewajiban itu, maka founding fatbers negara ini sejak awal telah mencantumkan jaminan atas hak pendidikan bagi rakyat Indonesia dalam Undang-Undang Dasar Negara, tepatnya pada Pasal 28. Dewasa ini, jaminan tersebut terus mengalami penyempurnaan melalui amandemen Undang-Undang Negara Republik Indonesiia Tahun 1945 Pasal 28c ayat (1) yang berbunyi:

Setiap orang bethak mengembangkan diri melalui pemenuhan kebutuhan dasarnya, berhak mendapat pendidikan dan memperoleh manfaat dari ilmu pengetahuan dan teknologi, seni dan budaya, demi meningkatkan kualitas hidupnya dan demi kesejahteraan umat manusia.

Bahkan pemerintah semakin memperkuat hak warga negara . untuk mendapatkan pendidikan yang layak melalui Undang-Undang Nomor 20 Tahun 2003 tentang Sistem Pendidikan Nasional, tepatnya pada Bab IV Pasal 5 ayat (1) yang berbunyi sebagai berikut: 
"Setiap warga negara mempunyai hak yang sama untuk memperoleh pendidikan yang bermutu."

Dalam Undang-undang tersebut juga dicantumkan secara eksplisit bahwa pihak yang wajib menyelenggarakan pedidikan bagi warga negara adalah Pemerintah dan Pemerintah Daerah. Aturan tersebut dapat dilihat dalam Pasal 11 ayat (1) dan (2) yang berbunyi sebagai berikut:

(1) Pemerintah dan Pemerintah Daerah wajib memberikan layanan dan kemudahan, serta menjamin terselenggaranya pendidikan yang bermutu bagi setiap warga negara tanpa diskriminasi.

(2) Pemerintah dan Pemerintah Daerah wajib menjamin tersedianya dana guna terselenggaranya pendidikan bagi setiap warga negara yang berusia tujuh sampai dengan lima belas tahun.

Dalam konteks inilah pemerintah harus melakukan refleksi dan terus bekerja maksimal untuk melaksanakan amanat undang-undang yang ternyata masih jauh dari hak yang seharusnya diterima rakyat. Apalagi Pemerintah Indonesia telah terikat dengan Deklarasi Millenium PBB yang ditandatangani pada September 2005 bersama 190 negara lain.

Dalam kaitan hal tersebut, sangatlah tepat upaya pemerintah dalam rangka peningkatan kualitas sumberdaya manusia yang diwujudkan dalam empat strategi kebijakan pendidikan: pemetataan, relevansi, mutu, dan efisiensi. Perluasan dan pemerataan kesempatan belajar bagi seluruh rakyat Indonesia tanpa membedakan lokasi tempat tinggal, status sosial ekonomi dan jenis kelamin diwujudkan dalam program Wajib Belajar 9 Tahun yang sebenarnya telah dicanangkan pada tahun 1994. Program Wajib Belajar 9 Tahun, dibarengi dengan pertumbuhan lapangan kerja dan keberhasilan program keluarga berencana diharapkan dapat memberi peluang dan kebebasan yang lebih luas bagi perempuan untuk ikut serta masuk pasar tenaga kerja dan berperan serta dalam pembangunan di segala bidang. Namun demikian, berbagai upaya yang telah dilakukan tentu mengalami berbagai hambatan, sehingga perlu terus dievaluasi untuk dapat merealisasikan kesetaaraan pendidikan yang nondiskriminatif. 


\section{Ekualitas Kesempatan Pendidikan}

Seperti dijelaskan di bagian terdahulu, peningkatan partisipasi perempuan dalam pembangunan sangat bergantung pada adanya ekualitas kesempatan (equality of opportunity) bagi perempuan dalam berbagai bidang pembangunan. Ekualitas kesempatan bagi perempuan dalam berbagai bidang sangat ditentukan oleh adanya ekualitas kesempatan pendidikan (equality of educational opportunity). Ekualitas kesempatan pendidikan di sekolah merupakan masalah yang penting daiam kaitannya dengan hak perempuan. Terbukanya ekualitas kesempatan pendidikan menjanjikan akses yang sama bagi perempuan terhadap dunia kerja. Tidak adnya ekualitas kesempatan pendidikan mengakibatikan terjadinya inekualitas distribusi penghasilan.

Secara sederhana, ekualitas kesempatan pendidikan berarti memberikan kesempatan dan peluang yang sama kepada setiap individu tanpa memandang latar belakang sosial, geografi, suku, agama, dan jenis kelamim untuk memperoleh pendidikan. Setiap orang mempunyai hak untuk memperoleh pendidikan, dan pemerintah berkewajiban menyediakan pendidikan.

Dalam pengkajian lebih lanjut tentang ekualitas kesempatan pendidikan selain ekualitas akses, juga perlu adanya ekualitas kurikalum dan ekualitas perlakuan.

\section{Ekualitas Akses Pendidikan}

Institusi pendidikan merupakan titik sentra dalam perjuangan perempuan untuk memperoleh akses yang sama terhadap pekerjaan. Memperoleh akses yang sama terhadap berbagai program pendidikan merupakan hal yang sangat pènting dalam perjuangan perempuan untuk memperoleh ekualitas kesempatan pekerjaan dan kesempatan lainnya.

Ekualitas akses pendidikan adalah pemerataan kesempatan yang sama bagi semua warga pria maupun perempuan untuk mamasuki pendidikan baik untuk pendidikan dasar, pendidikan kejuruan, maupun pendidikan kejuruạn, melalui jalur formal (sekolah) dan jalur non-formal (luar sekolah). Terjaminnya ekualitas akses pendidikan bagi pria dan perempuan diharapkan keadilan dalam pelayanan pendidikan akan tercapai. 


\section{Ekualitas dalam Sistem Persekolahan dan Kurikulum}

Ekualitas akses pendidikan barulah merupakan pintu gerbang pertama untuk tercapainya ekualitas kesempatan pendidikan. Sistem persekolahan dan kurikulum pendidikan mempunyai peran yang tidak kalah pentingnya dalam ekualitas kesempatan pendidikan. Disadari atau tidak, pengelompokkan institusi pendidikan (persekolahan) ke dalam bermacam jenis kejuruan dan program secara tidak disengaja (implisit) telah mengarah pada terciptanya segregasi gender di dunia pendidikan.

Dengan pertumbuhan pekerjaan kantor (wbite-collar occupations) yang semakin pesat, perempuan merupakan sumber tenaga kerja potensial untuk posisi administrasi kantor seperti sekretaris, pengetik; dan tenaga administrasi. Secara tidak sengaja sekolah telah berperan penting dalam melanggengkan segregasi gender dalam pekerjaan. Berbagai program pendidikan kejuruan dan spesialisasi bisnis dan kesekretariatan cenderung sebagian besar diikuti oleh perempuan. Hal ini berarti kurikulum yang khas perempuan (segregasi gender) telah mendorong terciptanya sektor pasar kerja yang mempunyai segregasi gender.

Institusi pendidikan hams mengambil tindakan yang positif untuk menjamin bahwa perempuan mempunyai akses yang sama kepada semua kurikum. Adanya sekolah-sekolah dan institusi pendidikan yang khusus menampung siswa dengan jenis kelamin tertentu, baik pria maupun perempuan, telah turut pula membentuk segregasi sekolah berdasarkan gender. Sekolah gabungan pria-perempuan (co-education)sering dianggap sebagai upaya untuk menghapuskan segregasi sekolah berdasarkan gender. Meskipun barangkali segregasi sekolah berdasarkan gender mempunyai beberapa keuntungan, namun segregasi sekolah berdasarkan gender juga seringkali membawa stigma inferioritas gender.

Petlakuan yang sama diperlukan bagi perempuan sebagai siswa dalam suatu institusi pendidikan untuk semua program pendidikan dan kurikulum. Ini berarti bahwa diskriminasi gender hams dikurangi dalam kurikulum pendidikan di mana pria merupakan mayoritas. Perempuan juga hams didorong untuk memasuki program-program pendidikan yang merupakan dominasi pria seperti 
dalam bidang IPA, teknologi dan perekayasaan. Kebijakan pengelompokkan siswa SMA, misalnya, ke dalam beberapa program studi secara implisit membentuk segregasi internal di dalam sekoiah. Dalam hal ini kebijakan penjurusan merupakan penolakan terhadap ekualitas kesempatan pendidikan.

Di samping sebagai siswa di.institusi pendidikan, perempuan sebagai pegawai institusi pendidikan juga hams mempunyai kesempatan yang sama untuk menduduki berbagai jabatan kependidikan. Kebijakan yang memberi peluang yang sama pada pria dan perempuan untuk memegang posisi administratif, misalnya, perlu dikembangkan.

\section{Ekualitas Perlakuan}

Ekualitas kesempatan pendidikan juga mengacu pada bagaimana anak diperlakukan setelah mereka memasuki sistem dan program pendidikan. Stigma dan harapan gum dan pendidik lainnya (self-fulfiling propbecy)yang menganggap siswa perempuan 'inferior' dalam bidang-bidang studi tertentu harus dihilañgkan. Program kegiatan olah raga siswa pria di sekolah yang seringkali memperoleh dukungan moral dan finansial lebih besar dari program kegiatan olah raga siswa perempuan kurang kondusif untuk tercapainya ekualitas perlakuan. Bias peran gender juga terjadi dalam cara guru memperlakukan dan memberi tugas siswa. Seringkali guru memberikan didikan mandiri lebih banyak kepada siswa pria dari pada siswa perempuan.

Stereotipe yang bernuansa peran gender di institusi pendidikan juga sangat penting dalam menjamin ekualitas kesempatan bagi pria dan perempuan. Isi kurikulum dan buku-buku pelajaran yang digunakan di sekolah harus terhindar dari stereotipe yang bermuatan peran gender ini.

\section{Partisipasi Perempuan Indonesia Dalam Pendidikan}

Walaupun dalam rangka mencerdaskan kehidupan bangsa, kebijakan Pemetintah tidak membedakan murid yang masuk ke sekolah baik formal maupun non-formal menurut jenis kelamin (gender neutral policy),namun dalam pelaksanaanya kebijakan tersebut tidaklah otomatis berdampak netral. Kenyataan ini tentu bukanilah sesuatu yang intensional (disengaja), tetapi lebih disebabkan karena berbagai kendala sosial, ekonomi, budaya, dan agama yang 
ada dalam masyarakat Namun dari waktu ke waktu, didorong oleh pertumbuhan ekonomi dan perubahan teknologi ketidaknetralan dalam implementasi kebijakan pendidikan tersebut telah menurun secara tajam sehingga mengurangi pembedaan peran (role differentiation) dan inekualitas gender(gender inequality).

\section{Buta Huruf}

Buta huruf di kalangan perempuan merupakan masalah yang.s sangat penting karena perempuan merupakan mayoritas tenaga produktif di daerah pedesaan, dan sebagai ibu memegang peranan sentral dalam perawatan dan pendidikan anak. Enam puluh prosen dari buta hurup perempuan di dunia adalah perempuan. Program pemberantasan buta hurup merupakan sarana untuk pemberdayaan perempuan(women empowerment)dalam memperbaiki statusnya dan dalam meningkatkan kesejahteraanya.

Dilihat dari upaya Pemerintah untuk memberantas buta hurup, persentase penduduk perempuan yang buta hurup $(16,1 \%)$ masih sekitar dua kali lipat persentase penduduk pria $(7,7 \%)$. Ketimpangan ini dengan jelas tergambarkan pada data seperti disajikan pada Tabel 1 yang menunjukkan bahwa disparitas penduduk buta hurup sangat besar antara penduduk pedesaan dan perkotaan. Penduduk buta hump sangat terkonsentrasi di pedesaan $(84,4 \%)$ dan hanya $15,6 \%$ berada di perkotaan. Lokasi tempat tinggal merupakan penyebab utama terkonsentrasinya penduduk buta hump.

Data empiris juga manunjukkan bahwa persentase angkatan kerja perempuan yang buta hump hampir dua kali lipat lebih besar $(33,6 \%)$ dibandingkan dengan persentase buta hump pria $(18,9 \%)$. Pencanangan Wajib Belajar 9 Tahun merupakan kebijakan yang tepat dalam mengurangi persentase penduduk buta hurup,khususnya di daerah pedesaan.

\section{Pendidikan Formal}

Pendidikan formal adalah sistem pendidikan dengan struktur hirarkis dan pengurutan (succession) kronologis jenjang pendidikan dari mulai sekolah dasar sampai pendidikan tinggi yang mencakup baik pendidikan umum dan kejuman.

Data empiris untuk pendidikan formal menunjukkan bahwa kesempatan untuk memperoleh pendidikan untuk perempuan relatif lebih kecil 
dibandingkan dengan kesempatan pendidikan yang diperoleh oleh pria. Hal ini dapat terlihat pada Tabel 2 sampai Tabel 4.

Tabel 2 menggambarkan jumlah murid bam (kelas 1) di setiap tingkatan pendidikan dari Sekolah Dasar sampai Perguman Tinggi. Data tersebut menunjukkan bahwa makin tinggi tingkat pendidikan makin kecil jumlah siswa/mahasiswa perempuan dibandingkan dengan pria. Murid baru kelas/tingkat 1 perempuan di tingkat SD adalah 47,28\% dan di PT (khusus PTN) hanya 40,31\%. Perbedaan ini cukup konsisten terjadi di setiap daerah dan provinsi.

Hal yang sama juga terjadi untuk data jumlah murid seperti terlihat pada Tabel 3. Semakin tinggi jenjang pendidikan makin kecil murid perempuan dibandingkan dengan murid pria. Di tingkat SD jumlah murid perempuan $48,37 \%$ sedangkan di tingkat perguruan tinggi adalah 36,3\%. Sementara untuk pria di tingkat SD 51,63\% dan di tingkat perguruan tinggi sebesar 63,68\%. Data empiris ini menunjukkan perbedaan yang relatif konsisten di setiap daerah dan propinsi.

Sebagai akibat langsung dari data di atas perbedaan jumlah dan persentase antara perempuan-pria juga terjadi pada data jumlah lulusan menurut tingkatan pendidikan seperti disajikan pada Tabel 4. Makin tinggi tingkat pendidikan makin kecil jumlah lulusan perempuan. Di tingkat SD terdapat 49,54\% perempuan dan di tingkat Pendidikan Tinggi menjadi 36,99\%.. Sementara lulusan pria tingkat SD sebesar 50,46\% dan menjadi $63,01 \%$ untuk tingkat perguruan tinggi.

Kenyataan di atas menunjukkan bahwa disparitas gender bersifat progresif (progressive gender disparity)sejalan dengan meningkatnya jenjang pendidikan. Semakin tinggi jenjang pendidikan semakin besar perbedaan jumlah dan persentase murid pria dan perempuan.

Dilihat dari jenis dan program pendidikan, data pada Tabel 2,3, dan 4 juga menggambarkan adanya disparitas jumlah dan persentase murid pria dan perempuan. Sekolah kejuruan dengan spesialisasi teknik didominasi murid pria, sementara sekolah kejuruan dengan spesialisasi ekonomi dan kesejahteraan keluarga didominasi murid perempuan. Pada jenjang pendidikan tinggi, 
disparitas gender juga semakin besar dari program non-gelar (S0) ke progtam gelar (S1).

Berbanding terbalik dengan data pada Tabel 2, 3, dan 4, dilihat dari jumlah murid yang mengulang, murid perempuan lebih kecil persentasenya dibanding murid pria untuk setiap tingkatan dan jenis sekolah seperti terlihat pada Tabel 5. Lebih jauh data pada tabel tersebut juga menunjukkan bahwa semakin tinggi jenjang pendidikan semakin "kecil jumlah murid perempuan yang mengulang. Sebaliknya, semakin tinggi pendidikan semakin banyak murid pria yang mengulang. Persentase mengulang murid perempuan' di SD adalah 48,37\% dan di SLTA 25,65\%, sebaliknya jumlah mengulang murid pria di SD adalah 51,63\% dan di SLTA meningkat menjadi 74,53\%.

Pada Tabel 6 disajikan jumlah murid putus sekolah (drop-out) berdasarkan tingkatan dan jenis sekolah. Data tersebut menunjukkan bahwa jumlah murid pria yang putus sekolah selalu lebih besar dari murid perempuan untuk semua jenjang pendidikan dari tingkat SD sampai perguruan tinggi. Di tingkat SD sebanyak $43,25 \%$ yang putus sekolah adalah perempuán dan $56,75 \%$ pria. Sedangkan di perguruan tinggi adalah hanya $8,66 \%$ yang putus kuliah adalah perempuan dan sisanya $(91,34 \%)$ adalah pria. Hal ini berarti mahasiswa perempuan yang masuk di Perguruan Tinggi Negeri telah tersaring dengan baik dan memiliki motivasi tinggi untuk sukses sehingga tidak terjadi jumlah putus kuliah yang tinggi dibandingkan dengan di tingkat yang lebih rendah.

Perbandingan antara jumlah dan persentase pria dan perempuan yang berkaitan dengan arus murid seperti mengulang kelas dan putus sekolah cukup menärik untuk diperhatikan. Perempuan ternyata memiliki daya tahan yang lebih baik untuk tetap tinggal di sekolah (retention) dibandingkan dengan pria. Hal ini juga dikaitkan dengan motivasi perempuan untuk sukses dalam pendidikan yang semakin konsisten sejalan dengan meningkatnya jenjang pendidikan.

Tabel 7 menyajikan data persentase melanjutkan untuk setiap tingkatan dan jenis sekolah. Secara umum, untuk setiap jenjang pendidikan persentase melanjutkan murid pria lebih besar dari murid perempuan. Sebanyak 57,69\% lulusan SD perempuan melanjutkan ke Sekolah Lanjutan Tingkat Pertama 
(SLTP), dan 64,92\% lulusan SD pria yang melanjutkan ke SLTP. Namun pada tingkat PTN, persentase melanjutkan ke PTN untuk perempuan $(7,66 \%)$ tidak begitu besar perbedaannya dengan pria (9,14\%). Perbandingan angka melanjutkan di setiap jenjang pendidikan untuk setiap provinsi menunjukkan persentase yang relatif sama.

Tabel 8 menyajikan angka partisipasi murni (APM) di tingkat SD (termasuk Madrasah Ibtidaiyah) tidak begitu banyak perbedaaannya antara perempuan dan pria yaitu berturut-turut 91,48\% dan 91,52\%. Di tingkat SLTP (termasuk Madrasah Tsanawiyah), angka partisipasi kasar (APK) cukup berbeda yaitu 49,62 untuk perempuan dan 56,25 untuk pria. Di tingkat Sekolah Lanjutan Atas, termasuk Madrasah Aliyah, angka partisipasi kasar (APK) 31,14\% untuk perempuan dan $38,67 \%$ untuk pria. Pada jenjang perguruan tinggi terjadi perbedaan yang cukup besar yaitu 4,64\% untuk perempuan dan 8,18 untuk pria.

Data di atas menunjukkan bahwa angka partisipasi perempuan semakin kecil sejalan dengan meningkatnya jenjang pendidikan. Sebaliknya, angka partisipasi pria semakin besar sejalan dengan meningkatnya jenjang pendidikan.

Tabel 9 menyajikan jumlah guru menurut jenis kelamin di setiap tingkatan dan jenis sekolah. Data pada tabel tersebut menunjukkan bahwa jumlah guru perempuan di jenjang Sekolah Dasar sedikit lebih banyak dari guru pria, berturut-turut $51,24 \%$ dan $48,76 \%$. Akan tetapi, semakin tinggi jenjang pendidikan jumlah guru pria semakin banyak dibanding guru perempuan. Guru perempuan di jenjang SD sebanyak 51,24\%, dan menurun tajam di jenjang perguruan tinggi (PTN) menjadi 24,03\%. Persentase dosen perempuan di PTN hanya seperempat dari seluruh dosen yang ada di PTN. Hal yang relatif konsisten juga ditemukan setelah data dipilah ke dalam provinsi.

\section{Pendidikan Non-Formal}

Yang dimaksud dengan pendidikan non-formal adalah semua kegiatan yang diorganisasi di luar sistem formal persekolahan baik yang berfungsi trepisah maupun sebagai bagian penting dari tujuan pendidikan.

Berbeda dengan jumlah murid di persekolahan, partisipasi perempuan pada pendidikan luar sekolah menunjukkan hal-hal yang cukup menarik. Tabel 10 sampai 12 menyajikan data pendidikan masyarakat yang terdiri dari jumlah 
warga belajar dan tamatan menunjukkan bahwa program pendidikan masyarakat merupakan program pendidikan yang mengarah pada pemberantasan buta huruf seperti Kejar Paket A dan Kejar Usaha cenderung didominasi oleh peserta perempuan. Tabel 10 menunjukkan bahwa jumlah warga belajar Kejar Paket A dan Kejar Usaha lebih banyak perempuan yaitu 54,92\% dan $\cdot 67,78 \%$. Sedangkan Kejar Paket B lebih banyak pria (60,32\%).

Sesuai dengan jumlah waraga belajar, jumlah tamatan Kejar Paket A dan B menunjukkan angka yang lebih besar pada tamatan perempuan dibandingkan dengan pria yaitu 53,93\% dan 57,27\%. Berdasarkan data pada tabel 12 diperoleh gambaran bahwa warga belajar Kejar Paket A yang terbanyak adalah yang berusia 7-12 tahun, sedangkan Kejar Paket B terbanyak adalah berusia 13. 29 tahun. Hal ini sangat mendukung program Wajib Belajar 9 Tahun.

Tabel 13 menyajikan data pembinaaan generasi muda dilihat dari jenis kelamin dari kegiatan. Data tersebut menunjukkan bahwa secara umum program-program kegiatan kepemudaan cenderung lebih didominasi oleh peserta pria yaitu sekitar 53,82\%. Hal ini menunjukkkan bahwa dalam pembinaan generasi muda yang lebih aktif adalah kaum pria.

Tabel 14 menyajikan data kegiatan olah raga dilihat dari jenis kelamin dan kegiatan. Seperti halnya program pembinaan generasi muda, program-program pembinaan keolahragaan baik dalam pemasalan olahraga maupun pembibitan olahraga juga lebih banyak didominasi oleh kaum pria. Bahkan olahraga dirgantara $100 \%$ dilaksanakan oleh pria. Olahraga yang paling banyak diminati kaum perempuan adalah pemasalan olahraga yang bersifat perorangan yaitu sebanyak $47,48 \%$ dibandingan dengan jenis olahraga lainnya.

\section{E. Penutup}

Walaupun dalam rangka mencerdaskan kehidupan bangsa, kebijakan Pemerintah tidak membedakan murid yang masuk ke sekolah baik formal maupun non-formal menurut jenis kelamin (gender neutral poligy),namun dalam pelaksanaanya kebijakan tersebut tidaklah otomatis berdampak netral. Data empiris menunjukkan bahwa dalam pendidikan formal masih terjadi Disparitas 
Gender Progresif. Partisipasi perempuan dalam. pendidikan formal semakin kecil sejalan dengan meningkatnya jenjang pendidikan.

Kenyataan ini lebih memprihatinkan apabila dikaitkan dengan partisipasi perempuan pekerja yang masih terkonsentrasi pada pekerja yang berpendidikan rendah, baik dilihat dari segi lapangan usaha, kategori jabatan, maupun status pekerjaan.

Dalam pendidikan non-formal partisipasi perempuan lebih tinggi dibanding pria. Namun hasil dari upaya ini belum sepenuhnya menghilangkan disparitas gender dilihat dari jumlah penduduk buta huruf. Jumlah penduduk buta huruf perempuan lebih besar dari pria. Hai ini juga berakibat terhadap besarnya persentase angkatan kerja perempuan yang buta huruf yang hampir dua kali lipat lebih besar dibandingkan dengan persentase buta huruf pria.

Pangkal dari terjadinya disparitas gender di dunia pendidikan ini sangat erat berkaitan dengan faktor agama, sosial, ekonomi, budaya, dan geografi. Meskipun dari segi hukum dan kebijakan pendidikan, pria dan perempuan diberikan ekualitas akses yang sama, betbagai kendala di atas membatasi perjuangan perempuan untuk memperoleh ekualitas kesempatan pendidikan. All men are created equal, but it is obvious that men and women are born into unequal circumstances.

Dalam kaitan ini tepat sekali konsep paradigma pasar yang dikemukakan oleh Fuchs (1983). Diberikan ekualitas akses yang sama, manusia (baca: orang tua) senantiasa dihadapkan pada keharusan memilih. Dalam membuat pilihan orang tua selalu berusaha berbuat yang terbaik dengan berbagai kendala yang dihadapinya (biaya, waktu, informasi, dsb.). Pilihan mereka dipengaruhi oleh suatu 'harga' relatif dilihat dari biaya, waktu, moral, dsb.. Pilihan mereka juga dipengaruhi oleh sejumlah faktor lain yang meliputi agama, budaya, sosial, ekonomi dan faktor eksternal lainnya.

Di samping adanya berbagai kendala di atas, di dunia pendidikan masih ditemui berbagai kebijakan yang secara tidak disengaja kurang mendukung tercapainya ekualitas program dan kurikulum pendidikan, dan ekualitas petlakukan di sekolah. Disparitas gender secara tidak disengaja telah terjadi pada institusi pendidikan baik pada status perempuan sebagai siswa maupun 
sebagai pegawai institusi pendidikan. Di institusi pendidikan seolah terjadi apa yang disebut men rule women and women rule cbildren.

Sangatlah tepat upaya Pemerintah mencanangkan Wajib Belajar 9 Tahun dalam upaya pemberdayaan perempuan. Program Wajar 9 Tahun ini tentu akan lebih mencapai sasatan apabila berbagai sistem penyampaiạ (delivery system)pendidikan dilakukan. 
208 Millab Vol. XII, No.1, Agustus 2012

LAMPIRAN

TABEL 1

JUMLAH DAN PERSENTASE BUTA HURUF

MENURUT JENIS KELAMIN SENSUS PENDUDUK 1990

\begin{tabular}{|l|l|l|l|l|l|}
\hline JENIS & DESA & $\%$ & KOTA & $\%$ & JUMLAH \\
\hline LAKI-LAKI & 6.057 .213 & 87,43 & 870.816 & 12,57 & 6.928 .029 \\
\hline PEREMPUAN & 12.085 .541 & 82,97 & 2.480 .547 & 17,03 & 14.566 .088 \\
\hline JUMIAH & 18.142 .754 & 84,41 & 3.351 .363 & 15,59 & 21.494 .117 \\
\hline
\end{tabular}

TABEL 2

JUMLAF MURD BARU 'TINGKAT' I

MENURU'T JENIS KELAMIN TIAP TINGKATAN DAN JENIS SEKOLAH

TAHUN 1992/93

\begin{tabular}{|c|c|c|c|c|c|}
\hline \multirow{2}{*}{ Tingkatan dan Jenis Sekolah } & \multicolumn{4}{|c|}{ Jenis Kelamin } & \multirow{2}{*}{ Jumlah } \\
\hline & Perempuan & $\%$ & Pria & $\%$ & \\
\hline Sekolah Dasar (SD) & 1998,656 & 47,28 & 2.228 .699 & 52.72 & 4.227 .355 \\
\hline $\begin{array}{l}\text { Sekolah Lanjutan Tingkat Pertama } \\
\text { (SLIP) }\end{array}$ & 938,555 & 46,59 & 1.075 .769 & 53,41 & 2.014 .324 \\
\hline $\begin{array}{l}\text { Umum/Sekolah Menengah Pertama } \\
\text { (SMP) }\end{array}$ & 933,009 & 46,90 & 1.056 .402 & 53,10 & 1.989 .411 \\
\hline Kejuruan \& Teknologi & 5,546 & 22,26 & 19,367 & 77,74 & 24,913 \\
\hline $\begin{array}{ll}\text { Sekolah Kesejahteraan Keluarga } \\
\text { Pertama(SKKP) }\end{array}$ & 4,983 & 97,82 & 111 & 2,18 & 5,094 \\
\hline Sekolah Teknik (ST) & 563 & 2,84 & 19,256 & 97,16 & 19,819 \\
\hline Sekolah Lanjutan Tingkat Atas (SLTA) & 557,710 & 42,55 & 753,041 & 57,45 & 1.310 .751 \\
\hline Umum/Sekolah Menengah Atas (SMA) & 366,856 & 44,56 & 456,494 & 55,44 & 823,350 \\
\hline Kejuruan \& Teknologi & 190,854 & 39,16 & 296,547 & 60,84 & 487,401 \\
\hline $\begin{array}{l}\begin{array}{l}\text { Sekolah Menengah Ekonomi } \\
\text { (SMEA) }\end{array} \\
\end{array}$ & 169,038 & 66,63 & 84,666 & 33,37 & 253,704 \\
\hline $\begin{array}{l}\text { Sekolah Menengah Kesejahteraan Klg. } \\
\text { (SMKK) }\end{array}$ & 17,197 & 95,79 & 755 & 4,21 & 17,952 \\
\hline Sekolah 'Teknik Menengah (STM) & 4,619 & 2,14 & 211,126 & 97,86 & 215,745 \\
\hline Perguruan Tinggi Negeri (PTN) & 39.987 & 40,31 & 59.206 & 59,69 & 99.193 \\
\hline Program S0 & 12.001 & 43,44 & 15.625 & 56.56 & 27.626 \\
\hline Program S1 & $27 ; 986$ & 39,10 & 43,581 & 60,90 & 71,567 \\
\hline
\end{tabular}


TABEL 3

JUMLAH MURID MENURUT JENIS KELAMIN

'TIAP TINGKATAN DAN JENIS SEKOLAH

TAHUN 1992/93

\begin{tabular}{|c|c|c|c|c|c|}
\hline \multirow{2}{*}{ Tingkatan dan Jenis Sekolah } & \multicolumn{4}{|l|}{ Jenis Kelamin } & \multirow{2}{*}{ Jumlah } \\
\hline & Petempuan. & $\%$ & Pria & $\%$ & \\
\hline Sekolah Dasar (SD) & 12.740 .956 & 48,37 & 13.599 .039 & 51,63 & 26.339 .995 \\
\hline $\begin{array}{l}\text { Sekolah Lanjutan Tingkat Pertama } \\
\text { (SLTP) }\end{array}$ & 2.550 .230 & 45,73 & 3.026 .810 & 54,27 & 5.577 .040 \\
\hline $\begin{array}{ll}\text { Umum/Sekolah } & \text { Menengah } \\
\text { Pertama (SMP) } & \\
\end{array}$ & 2.534 .704 & 46,15 & 2.957 .473 & 53,85 & 5.492 .177 \\
\hline Kejuruan \& Teknologi & 15,526 & 18,30 & 69,337 & 81,70 & 84.863 \\
\hline $\begin{array}{l}\text { Sekolah Kesejahteraan Keluarga } \\
\text { Pertama(SKKP) }\end{array}$ & 14,020 & 96,85 & 456 & 3,15 & 14.476 \\
\hline Sekolah Teknik (ST) & 1,506 & 2,14 & 68,881 & 97,86 & 70.387 \\
\hline $\begin{array}{l}\text { Sekolah Lanjutan Tingkat Atas } \\
\text { (SLTA) }\end{array}$ & 1.666 .299 & 44,24 & 2.100 .351 & 55,76 & 3.766 .650 \\
\hline $\begin{array}{l}\text { Umum/Sekolah Menengah Atas } \\
\text { (SMA) }\end{array}$ & 1.142 .885 & 46,03 & 1.340 .116 & 53,76 & 2.483 .001 \\
\hline Kejuruan \& Teknologi & 523,414 & 40,78 & 760,235 & 59,22 & $1,283.649$ \\
\hline $\begin{array}{l}\text { Sekolah Menengah Ekonomi Atas } \\
\text { (SMEA) }\end{array}$ & 464,352 & 68,06 & 217,911 & 31,94 & 682.263 \\
\hline $\begin{array}{l}\text { Sekolah Menengah Kesejahteraan } \\
\text { Klg. (SMKK) }\end{array}$ & 47,214 & 96,19 & 1,870 & 3,81 & 49.084 \\
\hline Sekolah Teknik Menengah (STM) & 11,848 & 2,15 & 540,454 & 97,85 & 552.302 \\
\hline Perguruan Tingoi Negeri (PTN) & 188,910 & 36,32 & 331,191 & 63,68 - & 520.101 \\
\hline Program SO - & 39,907 & 42,88 & 53,152 & 57,12 & 93.059 \\
\hline Program S1 & 149,003 & 34,89 & 278,039 & 65,11 & 427.042 \\
\hline
\end{tabular}


TABEL 4

JUMLAF LULUSANं MENURUT JENIS KELAMIN TIAP TINGKATAN DAN JENIS SEKOLAH

TAHUN 1992/93

\begin{tabular}{|l|l|l|l|l|c|}
\hline \multirow{2}{*}{ Tingkatan dan Jenis Sekolah } & \multicolumn{2}{|l|}{ Jenis Kelarin } & \multirow{2}{*}{ Jumlah } \\
\cline { 2 - 5 } & Perempuan & $\%$ & Pria & $\%$ & \\
\hline Sekolah Dasar (SD) & 1.626 .836 & 49,55 & 1.657 .095 & 50,46 & 3.283 .931 \\
\hline $\begin{array}{l}\text { Sekolah Lanjutan Tingkat Pertama } \\
\text { (SLIP) Umum/ }\end{array}$ & 757.117 & 46,16 & 883.316 & 53,36 & 1.640 .555 \\
\hline Sekolah Menengah Pertama (SMP) & 752.117 & 46,64 & 860.378 & 53,36 & 1.612 .495 \\
\hline Kejuruan \& Teknologi & 5,122 & 18,25 & 22,938 & 81,75 & 28,060 \\
\hline $\begin{array}{l}\text { Sekolah Kesejahteraan Keluatga } \\
\text { Pettama(SKKP) }\end{array}$ & 4,726 & 97,06 & 143 & 2,94 & 4,869 \\
\hline Sekolah Teknik (ST) & 396 & 1,71 & 22,795 & & 23,191 \\
\hline $\begin{array}{l}\text { Sekolah Ianjutan Tingkat Atas } \\
\text { (SLTA) }\end{array}$ & 521,792 & 44,62 & 2647,590 & 55,38 & 1.169 .382 \\
\hline $\begin{array}{l}\text { Umum/Sekolah Menengah Atas } \\
\text { (SMA) }\end{array}$ & 371,818 & $5: 24$ & 450,105 & 54,76 & 821,923 \\
\hline Kejuruan \& Teknologi & 149,974 & 43,16 & 197,485 & 56,84 & 347,459 \\
\hline $\begin{array}{l}\text { Sekolah Menengah Ekonomi Atas } \\
\text { (SMEA) }\end{array}$ & 133,565 & 68,19 & 62,314 & 31,81 & 195,879 \\
\hline $\begin{array}{l}\text { Sekolah Menengah Kesejahteraan } \\
\text { Klg.(SMKK) }\end{array}$ & 13,399 & 96,63 & 468 & 3,37 & 13,867 \\
\hline Sekolah Teknik Menengah (STM) & 3,010 & 2,19 & 134,703 & 97,81 & 137,713 \\
\hline Perguruan Tinggi Negeri (PIN) & 26,899 & 36,99 & 45,816 & 63,01 & 72,715 \\
\hline Program S0 & 8,180 & 39,19 & 12,714 & 60,85 & 20,894 \\
\hline Program S1 & 18,719 & 36,12 & 33,102 & 63,88 & 51,821 \\
\hline
\end{tabular}

TABEL 5

JUMLAH MENGULANG MENURU'T JENIS KELAMIN

TTAP TTNGKA'TAN DAN JENIS SEKOLAH

TAHUN 1992/93

\begin{tabular}{|l|l|l|l|l|l|}
\hline \multirow{2}{*}{ Tingkatan dan Jenis Sekolah } & \multicolumn{4}{|l}{ Jenis Kelamin } & \multirow{2}{*}{ Jumlah } \\
\cline { 2 - 6 } & Perempuan & $\%$ & Pria & $\%$ & \\
\hline Sekolah Dasar (SD) & 1129,187 & 48,37 & 1.205 .230 & 51,63 & 2.334 .417 \\
\hline $\begin{array}{l}\text { Sekolah Lanjutan Tingkat Pertama } \\
\text { (SLTP) Umum/ }\end{array}$ & 17.810 & 30,66 & 40.271 & 69,34 & 58.081 \\
\hline Sekolah Menengah Pettama (SMP) & 17.681 & 31,01 & 39.330 & 68,34 & 57.011 \\
\hline Kejuruan \& Teknologi & 129 & 12,06 & 941 & 87,94 & 1,070 \\
\hline
\end{tabular}




\begin{tabular}{|l|l|l|l|l|l|}
\hline $\begin{array}{l}\text { Sekolah Kesejahteraan Keluarga } \\
\text { Pertama(SKKP) }\end{array}$ & 101 & 97,12 & 3 & 2,88 & 104 \\
\hline Sekolah Teknik (ST) Tingkat Atas & 28 & 2,90 & 938 & 97,10 & 966 \\
\hline $\begin{array}{l}\text { Sekolah Lanjutan } \\
\text { (SLTA) }\end{array}$ & 8,563 & 25,65 & 24,821 & 74,35 & 33,384 \\
\hline $\begin{array}{l}\text { Umum/Sekolah Menengah Atas } \\
\text { (SMA) }\end{array}$ & 6,403 & 26,78 & 17,510 & 73,22 & 23,913 \\
\hline Kejuruan \& Teknologi & 2,160 & 22,81 & 7,311 & 77,19 & 9,471 \\
\hline $\begin{array}{l}\text { Sekolah Menengah Ekonomi Atas } \\
\text { (SMEA) }\end{array}$ & 1,728 & 44,78 & 2,131 & 55,22 & 3,859 \\
\hline $\begin{array}{l}\text { Sekolah Menengah Kesejahteraan } \\
\text { Keluarga(SMKK) }\end{array}$ & 343 & 92,45 & 28 & 7,55 & 371 \\
\hline Sekolah Teknik Menengah (STM) & 89 & $1,70$. & 5,152 & 98,30 & 5,241 \\
\hline
\end{tabular}

TABEL 6

JUMLAH MURID PUTUS SEKOLAH MENURUT JENIS KELAMIN TIAP TINGKATAN DAN JENIS SEKOLAH

TAHUN 1992/93

\begin{tabular}{|l|l|l|l|l|l|}
\hline \multirow{2}{*}{ Tingkatan dan Jenis Sekolah } & \multicolumn{3}{l}{ Jenis Kelamin } & \multirow{2}{*}{ Jumlah } \\
\cline { 2 - 6 } & Perempuan & $\%$ & Pria & $\%$ & \\
\hline Sekolah Dasar (SD) & 401,893 & 43,25 & 527,237 & 56,75 & 929,130 \\
\hline $\begin{array}{l}\text { Sekolah Lanjutan Tingkat Pertama } \\
\text { (SLPP) }\end{array}$ & 193,543 & 48,24 & 207,701 & 51,76 & 401,244 \\
\hline $\begin{array}{l}\text { Umum/Sekolah Menengah Pertama } \\
\text { (SMP) }\end{array}$ & 191,460 & 48,47 & 203,566 & $-51,53$ & 395,026 \\
\hline Kejuruan \& Teknologi & 2,083 & 33,50 & 4,135 & 66,50 & 6,218 \\
\hline $\begin{array}{l}\text { Sekolah Kesejahteraan Keluarga } \\
\text { Pertama(SKKP) }\end{array}$ & 1,937 & 99,95 & 1 & 0,05 & 1,938 \\
\hline Sekolah Teknik (ST) & 146 & 3,41 & 4,134 & 96,59 & 4,280 \\
\hline Sekolah Lanjutan Tingkat Atas (SLTA) & 98,974 & 45,88 & 116,728 & 54,12 & 215,702 \\
\hline $\begin{array}{l}\text { Umum/Sekolah Menengah Atas } \\
\text { (SMA) }\end{array}$ & 43,708 & 43,02 & 57,886 & 56,98 & 101,594 \\
\hline Kejuruan \& Teknologi & 55,266 & 48,43 & 58,842 & 51,57 & 114,108 \\
\hline $\begin{array}{l}\text { Sekolah Menengah Ekonomi Atas } \\
\text { (SMEA) }\end{array}$ & 51,174 & 68,84 & 23,162 & 31,16 & 74,336 \\
\hline $\begin{array}{l}\text { Sekolah Menengah Kesejahteraan Klg. } \\
\text { (SMKK) }\end{array}$ & 3,591 & 99,86 & 5 & 0,14 & 3,596 \\
\hline Sekolah Teknik Menengah (STM) & 501 & 1,38 & 35,675 & 98,62 & 36,176 \\
\hline Perguruan Tinggi Negeri (PIN) & 20,216 & 8,66 & 213.305 & 91,34 & 233,521 \\
\hline Program S0 & 2,174 & 5,65 & 36.281 & 94,35 & 38,455 \\
\hline Program S1 & 18,042 & 9,25 & 177,024 & 90,75 & 195,066 \\
\hline
\end{tabular}


TABEL 7

ANGKA MELANJUTKAN MENURUT JENIS KELAMIN TIAP TINGKATAN DAN JENIS SEKOLAH

TAHUN 1992/93

\begin{tabular}{|l|l|l|l|}
\hline \multirow{2}{*}{ Tingkatan dan Jenis Sekolah } & \multicolumn{2}{l}{ Jenis Kelamin } & \multirow{2}{*}{ Jumlah } \\
\cline { 2 - 3 } & Perempuan & \multirow{2}{*}{ Pria } & \\
\hline Sekolah Lanjutan Tingkat Pertama (SLTP) & 57,69 & 64,92 & 61,34 \\
\hline Umum/Sekolah Menengah Pertama (SMP) & 57,35 & 63,75 & 60,58 \\
\hline Kejuruan \& Teknologi & 0,34 & 1,17 & 0,76 \\
\hline Sekolah Kesejahteraan Klg. Pertama (SKKP) & 0,31 & 0,01 & 0,16 \\
\hline Sekolah Teknik (ST) & 0,03 & 1,16 & 0,60 \\
\hline Sekolah Lanjutan Tingkat Atas (SLTA) & 59,42 & 70,00 & 65,07 \\
\hline Umum/Sekolah Menengah Atas (SMA) & 39,09 & 42,43 & 40,87 \\
\hline Kejuruan \& Teknologi & 20,33 & 27,57 & 24,20 \\
\hline Sekolah Menengah Ekonomi Atas (SMEA) & 18,01 & 7,87 & 12,59 \\
\hline Sekolah Menengah Kesejahteraan Klg. (SMKK) & 1,83 & 0,07 & 0,89 \\
\hline Sekolah Teknik Menengah (STM) & 0,49 & 19,63 & 10,71 \\
\hline Perguruan Tinggi Negeri (PTN) & 7,66 & 9,14 & 8,48 \\
\hline Program SO & 2,30 & 2,41 & 2,36 \\
\hline Program S1 & 5,36 & 6,73 & 6,12 \\
\hline
\end{tabular}

TABEL 8

ANGKA PARTISIPASI MENURUT JENIS KELAMIN

TIAP TINGKA'TAN DAN JENIS SEKOLAH

- TAHUN 1992/93

\begin{tabular}{|l|l|l|l|}
\hline \multirow{2}{*}{ Tingkatan dan Jenis Sekolah } & \multicolumn{2}{|l|}{ Jenis Kelamin } & \multirow{2}{*}{ Rata-rata } \\
\cline { 2 - 4 } & Perempuan & Pria & \\
\hline Sekolah Dasar (SD) & 91,48 & 91,52 & \multirow{2}{*}{91,50} \\
\hline Sekolah Lanjutan Tingkat Pertama (SLTP) & 56,25 & 49,62 & 53,01 \\
\hline Sekolah Lanjutan Tingkat Atas (SLTA) & 38,67 & 31,14 & 34,93 \\
\hline Perguruan Tinggi Negeri (PTN) & 8,18 & 4,64 & 6,31 \\
\hline
\end{tabular}

Catatan: Khusus SD angka partisipasi murni (APM) Selain SD angka partisipasi kasar (APK) 
TABEL 9
JUMLAH GURU MENURUT JENIS KELAMTN
TIAP TINGKATAN DAN JENIS SEKOLAH
TAHUN 1992/93

\begin{tabular}{|l|l|l|l|l|l|}
\hline \multirow{2}{*}{ Tingkatan dan Jenis Sekolah } & \multicolumn{2}{l}{ Jenis Kelamin } & \multirow{2}{l}{ Jumlah } \\
\cline { 2 - 6 } & Perempuan & $\%$ & Pria & $\%$ & \\
\hline Sekolah Dasar (SD) & 591.239 & 51,24 & 562.577 & 48,76 & 1.153 .816 \\
\hline $\begin{array}{l}\text { Sekolah Lanjutan Tingkat Pertama } \\
\text { (SLTP) }\end{array}$ & 149.080 & 38.96 & 233.668 & 61,05 & 382.748 \\
\hline $\begin{array}{l}\text { Umum/Sekolah Menengah Pertama } \\
\text { (SMP) }\end{array}$ & 146.507 & 39,04 & 228.806 & 60,96 & 375.313 \\
\hline Kejuruan \& Teknologit & 2.573 & 34,61 & 4.862 & 65,39 & 7.436 \\
\hline $\begin{array}{l}\text { Sekolah Kesejahteraan Keluarga Pertama } \\
\text { (SKKP) }\end{array}$ & 1.215 & 79,57 & 312 & 20.43 & 1.527 \\
\hline Sekolah Teknik (ST) & 1.358 & 22.99 & 4.550 & 77,01 & 5.908 \\
\hline Sekolah Lanjutan Tingkat Atas (SLTA) & 98.338 & 32,95 & 200.113 & 67,05 & 298.451 \\
\hline Umum/Sekolah Menengah Atas (SMA) & 71.880 & 35,34 & 131.528 & 64,66 & 203.408 \\
\hline Kejuruan \& Teknologi & 26.458 & 27.84 & 68.585 & 72,16 & 95.043 \\
\hline $\begin{array}{l}\text { Sekolah Menengah Ekonomi Atas } \\
\text { (SMEA) }\end{array}$ & 16.046 & 33,47 & 31.896 & 66,53 & 47.942 \\
\hline $\begin{array}{l}\text { Sekolah Menengah Kesejahteraan Klg. } \\
\text { (SMKK) }\end{array}$ & 3.540 & 75,06 & 1.176 & 24,94 & 4.716 \\
\hline Sekolah Teknik Menengah (STM) & 6.872 & 16,21 & 35.513 & 83,79 & 42.385 \\
\hline Perguruan Tinggi Negeri (PTN) & 10.887 & 24,03 & 34.414 & 75,97 & 45.301 \\
\hline
\end{tabular}

TABEL 10

JUMLAH WARGA BELAJAR MENÜRUT JENIS KELAMIN TLAP JENIS KEGIATAN

TAHUN 1992/93

\begin{tabular}{|l|l|l|l|l|l|}
\hline \multirow{2}{*}{ Jenis Kegiatan } & \multicolumn{3}{|l|}{ Jenis Kelamin } & \multirow{2}{*}{ Jumlah } \\
\cline { 2 - 6 } & Perempuan & $\%$ & Pria & $\%$ & \\
\hline Kejar Paket A & 369,904 & 54,92 & 303,658 & 45,08 & 673,562 \\
\hline Kejar Paket B & 2,421 & 39,68 & 3,680 & 60,32 & 6,101 \\
\hline Kejar Usaha & 100,609 & 67,78 & 47,821 & 32,22 & 148,430 \\
\hline
\end{tabular}


214 Millab.Vol. XII, No.1, Agustus 2012

TABEL 11

JUMLAH TAMATAN WARGA BELAJAR MENURU'T JENIS KELAMIN TIAP JENIS KEGIA'TAN

TAHUN 1992/93

\begin{tabular}{|l|l|l|l|l|l|}
\hline \multirow{2}{*}{ Jenis Kegiatan } & \multicolumn{4}{|c|}{ Jenis Kelamin } & \multirow{2}{*}{ Jumlah } \\
\cline { 2 - 5 } & Perempuan & $\%$ & Pria & $\%$ & \\
\hline Kejar Paket A & 254.505 & 53,93 & 217.402 & 46,07 & 471.907 \\
\hline Kejar Paket B & 2.668 & 57,27 & 1.991 & 42,73 & 4.659 \\
\hline
\end{tabular}

TABEL 12

JUMLAH WARGA BELAJAR MENURUT KELOMPOK USIA DAN JENIS KELAMIN TIAP JENIS KEGIATAN

TAHUN 1992/93

\begin{tabular}{|c|l|l|l|l|l|}
\hline \multirow{2}{*}{ Jenis Kegiatan } & \multicolumn{3}{|l|}{ Jenis Kelamin } & \multirow{2}{*}{ Jumlah } \\
\cline { 2 - 5 } & Perempuan & $\%$ & Pria & $\%$ & \\
\hline Kejar Paket A & 369,904 & 54,92 & 303,658 & 45,08 & 673,562 \\
\hline $7-12$ th & 18,111 & 56,08 & 14,185 & 43,92 & 32,296 \\
\hline $13-44$ th & 323,064 & 55,02 & 264,131 & 44,98 & 587,195 \\
\hline$>45$ th & 28,729 & 53,13 & 25,342 & 46,87 & 54,071 \\
\hline Kejar Paket B & 2,421 & 39,68 & 3,680 & 60,32 & 6,101 \\
\hline $13-29$ th & 1,729 & 43,21 & 2,272 & 56,79 & 4,001 \\
\hline $30-44$ th & 662 & 34,02 & 1,284 & 65,98 & 1,946 \\
\hline$>45$ th & 30 & 19,48 & 124 & 80,52 & 154 \\
\hline
\end{tabular}

Tabel 13

JUMLAH PESER'TA KEGLATAN KEPEMUDAAN MENURUT JENIS KELAMIN TLAP JENIS KELAMEN

TAHUN 1992/93

\begin{tabular}{|l|l|l|l|l|l|}
\hline \multirow{2}{*}{ Jenis Kegiatan } & \multicolumn{2}{|l|}{ Jenis Kelamin } & \multirow{2}{*}{ Jumlah } \\
\cline { 2 - 6 } & Perempuan & $\%$ & Pria & $\%$ & \\
\hline Kepemimpinan dan Ketrampilan & 2.279 .722 & 46,74 & 2.597 .372 & 53,26 & 4.877 .094 \\
\hline Kesegaran Jasmani \& Daya Kreasi & 1.237 .200 & 47,63 & 1.360 .069 & 52,37 & 2.597 .269 \\
\hline
\end{tabular}


Perempunan Dan Pendidikan Dalam Perspektif HAM... 215

\begin{tabular}{|l|l|l|l|l|l|}
\hline Patriotisme dan Idealisme & 3.293 .230 & 46,21 & 3.833 .704 & 53,79 & 7.126 .934 \\
\hline Kesadaran Bërbangsa \& Bernegara & 274,413 & 42,18 & 376,235 & 57,82 & 650,648 \\
\hline Kepribadian dan Budi Pekeri & 366,810 & 45,76 & 434,707 & 54,24 & 801,517 \\
\hline Peningkatan \& Perluasan Partisipasi & 802,290 & 44,09 & 1.017 .422 & 55,91 & 1.819 .712 \\
\hline Jumlah & 8.253 .665 & 46,18 & 9.619 .509 & 53,82 & 17.873 .174 \\
\hline
\end{tabular}

TABEL 14

JUMLAH PESERTA KEGIATAN OLAHRAGA MENURUT JENIS KELAMIN TIAP KEGIATAN

TAHUN 1992/93

\begin{tabular}{|c|c|c|c|c|c|}
\hline \multirow{2}{*}{ Jenis Kegiatan } & \multicolumn{4}{|c|}{ Jenis Kelamin } & \multirow{2}{*}{ Jumlah } \\
\hline & Perempuan & $\%$ & Pria & $\%$ & \\
\hline Pemasalan Olahraga & 8.822 .48 & 45,06 & 10.758 .648 & 54,94 & 19.581 .134 \\
\hline Olahraga Beregu & 2.728 .468 & 41,77 & 3.803 .155 & 58,23 & 6.531 .623 \\
\hline Olahraga Perorangan & 5.383 .136 & 47,48 & 5.953 .819 & 52,52 & 11.336 .955 \\
\hline Olahraga Dual & 231,564 & 41,19 & 330,608 & 58,81 & 562,172 \\
\hline Olahraga Beladiri & 67,933 & 46,26 & 78,915 & 53,74 & 146,848 \\
\hline Olahraga Pemairan & 4,576 & 31,65 & 9,881 & 68,35 & 14,457 \\
\hline Olahraga Dirgantara & 662 & 37,74 & 1,092 & 62,26 & 1,754 \\
\hline Olahraga Ketangkasan & 45,351 & 32,31 & 95,007 & 67,69 & 140,358 \\
\hline Olahraga Tradisional & 360,796 & 42,60 & 486,171 & 57,40 & 846,967 \\
\hline Pembibitan Olahraga & 1738,429 & 36,73 & 2.994 .758 & 63,27 & $4.733,187$ \\
\hline Olahraga Beregu & 660,925 & 29,36 & 1.590 .187 & 70,64 & 2.251 .112 \\
\hline Olahraga Perorangan & 600,939 & 45,23 & 727,809 & 54,77 & 1.328 .748 \\
\hline Olahraga Dual & 380,222 & 43,00 & 503,985 & 57,00 & 884,207 \\
\hline Olahraga Beladiti & 35,196 & 36,66 & 60,819 & 63,34 & 96,015 \\
\hline Olahraga Petaiman & 423 & 23,63 & 1,367 & 76,37 & 1,790 \\
\hline Olahraga Dirgantara & 0 & 0,00 & 670 & 100,00 & 670 \\
\hline Olahraga Ketangkasan & 39,454 & 32,14 & 83,317 & 67,86 & 122,771 \\
\hline Olahraga 'Tradisional & 21,270 & 44,43 & 26,604 & 55,57 & 47,874 \\
\hline
\end{tabular}


216 Millab Vol. XII, No.1, Agustus 2012

\section{DAFTAR PUSTAKA}

Achmad, Syamsiah. 1993. "Pengembangan Dukungan Ilmiah Bagi Peningkatan Peranan Perempuan." dalam Makalah yang disampaikan pada Forum Komunikasi Hasil Penelitian, Direktorat Pembinaan Penelitian dan Pengabdian pada Masyarakat, Ditjen Dikti, Depdikbud, Cisarua-Bogor.

Djojonegoro, Wardiman (Februari 1994). "Pendidikan dan Peningkatan

Peranan Perempuan dalam Pembangunan Nasional." dalam Makalah disampaikan pada Rapat Kordinasi Menteri Utusan Perempuan, Jakarta.

Fuchs, Victor R. 1983. How We Live. Cambridge, MA: Harvard University Press. Hallak, J. (1990) Investing in the Future. Oxford, UK: UNESCO-IEPPergamon Press.

Maturbongs, R. T. D. 1993. "Kendala dalam Meningkatkan Pendidikan Perempuan di Irian Jaya." dalam Makalah yang disampaikan pada Forum Komunikasi Hasil Penelitian, Direktorat Pembinaan Penelitian dan Pengabdian pada Masyarakat, Ditjen Dikti, Depdikbud, Cisarua-Bogor.

Napitupulu, W.P. 1989. On Literacy in Indonesia. Jakarta: Ministry of Education and Culture.

Oey-gardiner, M. 1993. "Perbedaan Gender dalam Hubungan Pendidikan dan Kerja." dalam Makalah yang disampaikan pada Forum Komunikasi Hasil Penelitian, Direktorat Pembinaan Penelitian dan Pengabdian pada Masyarakat, Ditjen Dikti, Depdikbud, Cisarua-Bogor.

Soemirat, Juli. 1993. "Beberapa Faktor yang Berpengaruh Terhadap Partisipasi - Perempuan dalam Pendidikan IPTEK" dalam Makalah yang disampaikan pada Forum Komunikasi Hasil Penelitian, Direktorat Pembinaan Penelitian dan Pengabdian pada Masyarakat, Ditjen Dikt, Depdikbud, Cisarua-Bogor. Spiing, J. 1989. American Education: An Introduction to Social and Political Aspects (4th ed). New York: Longman Inc.

Sudrajat, I. dan Sṭi Rahayu. 1993. "TPTEK Berwawasan Gender." dalam Makalah yang disampaikan pada Forum Komunikasi Hasil Penelitian, 
Direktorat Pembinaan Penelitian dan Pengabdian pada Masyarakat, Ditjen Dikti, Depdikbud, Cisarua-Bogor.

Suleeman, E. 1993. "Pendidikan Perempuan Indonesia." dalam Makalah yang disampaikan pada Forum Komunikasi Hasil Penelitian, Direktorat Pembinaan Penelitian dan Pengabdian pada Masyarakat, Ditjen Dikti, Depdikbud, Cisarua-Bogor. 